\title{
Laktátszintváltozások diabeteses ketoacidosisban és frissen diagnosztizált 1-es típusú diabetes mellitusban
}

\author{
Jenei Kinga dr. ${ }^{1}$ - Szatmári Ildikó dr. ${ }^{1}$ \\ Szabó Eszter dr. ${ }^{1}$ - Mariam Anjum dr. ${ }^{2}$ - Luczay Andrea dr. ${ }^{1}$ \\ Zsidegh Petra dr. ${ }^{1}$. Tóth-Heyn Péter dr. ${ }^{1}$ \\ ${ }^{1}$ Semmelweis Egyetem, Általános Orvostudományi Kar, I. Gyermekgyógyászati Klinika, Budapest \\ ${ }^{2}$ Telemark Hospital, Telemark, Norway
}

\begin{abstract}
Bevezetés: A klinikumban ismert a diabeteses ketoacidosisban (DKA) kialakuló hyperlactataemia, azonban a háttérben álló mechanizmusok és a változások kinetikája tisztázatlan. Az emberi szervezetben fiziológiásan fơleg a laktát L-izomere van jelen. Hyperglykaemiás állapotokban azonban fokozott lehet a D- és L-laktát-termelés is, így a szöveti hypoperfusio mellett ez a tényező is szerepet játszhat a laktátváltozásokban.

Célkitüzés: Vizsgálatunk célja a ketoacidosisban és a frissen diagnosztizált diabetesben jelentkező laktátváltozások kinetikájának és mechanizmusának feltérképezése volt.

Módszer: Ketoacidosis (DKA-csoport, $\mathrm{n}=13$ ) és frissen diagnosztizált l-es típusú diabetes mellitus (T1DM-csoport, $\mathrm{n}=6$ ) miatt felvett 5-18 éves gyermekek prospektív vizsgálata történt. A felvételt követően 0-12-24-48 órával vérgázvizsgálatot végeztünk, mely az L-laktát-koncentráció meghatározására is alkalmas. Minden idópontban meghatároztuk az összlaktátot $(\mathrm{L}+\mathrm{D})$ is gázkromatográfíás tömegspektrometriával.

Eredmények: Felvételkor minden ketoacidoticus betegnél kórosan magas L-laktát-koncentrációt mértünk, ami magasabb volt, mint a T1DM-csoportban $(\mathrm{p}<0,05) .12$ óra elteltével az L-laktát-szint ketoacidosisban csökkent, majd ismét megemelkedett 24 és 48 óra után $(\mathrm{p}<0,01)$. A T1DM-csoportban csak a 48 órás érték emelkedett szignifikánsan ( $\mathrm{p}<0,05$ versus 12 óra). $0-12$ óra között az összlaktát-koncentráció jelentősen meghaladta az L-laktát-szintet, ez a D-laktátot tükröző különbség fokozatosan csökkenve 48 óra után megszúnt.

Következtetés: A ketoacidosisban észlelt két laktátcsúcs közül az első 12 órában a hyperlactataemia kialakulásában az anaerob glikolízisnek van szerepe. A második, inzulinkezelés és rendezett folyadékháztartás mellett kialakuló csúcs hátterében fokozott aerob glikolízis állhat. Az L-laktát- és összlaktátszintek közötti kezdeti különbség D-laktát képződésére utal, amely a ketoacidosis kezdeti fázisában az L-laktáttal azonos nagyságrendben termelődik.

Orv Hetil. 2019; 160(45): 1784-1790.
\end{abstract}

Kulcsszavak: diabetes mellitus, laktát, ketoacidosis

\section{Changes of lactate levels in diabetic ketoacidosis and in newly diagnosed type 1 diabetes mellitus}

Introduction: It is known that lactate concentration is increased in diabetic ketoacidosis (DKA), however, the pathophysiology and kinetics of lactate changes are still unclear. Normally, L-lactate is the major form in the human body. According to previous data, also D- and L-lactate might be increased in hyperglycaemic disorders.

Aim: We aimed to describe the kinetics and mechanisms of lactate concentration changes in ketoacidosis and newly diagnosed diabetes.

Method: We performed a prospective study, including 5-18-year-old children with ketoacidosis (DKA, $\mathrm{n}=13$ ) and with newly diagnosed type 1 diabetes without ketoacidosis (TIDM, $\mathrm{n}=6$ ). We performed routine blood gas analysis 0-12-24-48 hours after admission, which also measured L-lactate levels. We also determined total venous serum lactate level by gas chromatography-mass spectrometry.

Results: Initial plasma lactate concentration was increased in ketoacidosis as compared to the newly diagnosed diabetes group $(\mathrm{p}<0.05)$. After $12 \mathrm{~h}$ of rehydration, lactate levels were greatly reduced in ketoacidotic patients but after $24-48 \mathrm{~h}$ it was repeatedly increased $($ all $\mathrm{p}<0.01$ ). In the $0-12 \mathrm{~h}$ phase, total serum lactate level was higher than L-lactate level, referring to D-lactate production. 
Conclusion: We described two L-lactate peaks in ketoacidosis. In the first 12 hours anaerobic glycolysis seems to have major role in hyperlactataemia. We assume that stimulated aerobic glycolysis leads to the second lactate peak. However, D-lactate is not routinely measured, it may contribute to the initial hyperlactataemia in both groups and is comparable to L-lactate production in ketoacidosis.

Keywords: diabetes mellitus, lactate, diabetic ketoacidosis

Jenei K, Szatmári I, Szabó E, Anjum M, Luczay A, Zsidegh P, Tóth-Heyn P. [Changes of lactate levels in diabetic ketoacidosis and in newly diagnosed type 1 diabetes mellitus]. Orv Hetil. 2019; 160(45): 1784-1790.

(Beérkezett: 2019. május 15.; elfogadva: 2019. július 2.)

\section{Rövidítések}

$\mathrm{DKA}=$ diabeteses ketoacidosis; ISPAD $=($ International Society for Pediatric and Adolescent Diabetes) Gyermek- és Serdülőkori Cukorbetegség Nemzetközi Társasága; LDH = laktátdehidrogenáz; NADH = nikotinamid-adenin-dinukleotid; TIDM = 1-es típusú diabetes mellitus

A diabeteses ketoacidosis (DKA) az l-es típusú diabetes mellitus potenciálisan halálos, még napjainkban is gyakori, akut szövődménye. Hazánkban az újonnan diagnosztizált diabeteses gyermekek több mint 30\%-a kerül ketoacidosis állapotában kórházba [1]. Ezen kívül is viszonylag gyakori a DKA a már inzulinnal kezelt, rossz anyagcsere-egyensúlyban lévő gyermekeknél [2]. Fontos megjegyezni, hogy kivételes esetekben DKA kialakulhat 2-es típusú diabetesben is. Egyéb kórokok mellett az utóbbi években számos esettanulmány számolt be nátrium-glükóz-kotranszporter-2 típusú antidiabetikumok (kiemelten a dapagliflozin) alkalmazása mellett kialakuló euglykaemiás ketoacidosisról [3-5].

A DKA a relatív vagy abszolút inzulinhiány és az egyidejűleg fokozottan felszabaduló ellenreguláló hormonok hatásának következményeként kialakuló akut anyagcserezavar, melyet hyperglykaemia, ketonaemia, metabolikus acidosis és hyperlipidaemia jellemez. Mindemellett a vizelet cukor- és ketontartalmának növekedése ozmotikus diuresist okoz, súlyos extracelluláris és intracelluláris folyadék- és elektrolithiányt, dehidrációt előidézve [6]. A DKA protokoll szerinti ellátása során szinte általános megfigyelés továbbá, hogy a DKA hyperlactataemiával jár együtt, ami szintén hozzájárul az acidosishoz (1. ábra). A hyperlactataemia a DKA patofiziológiájának

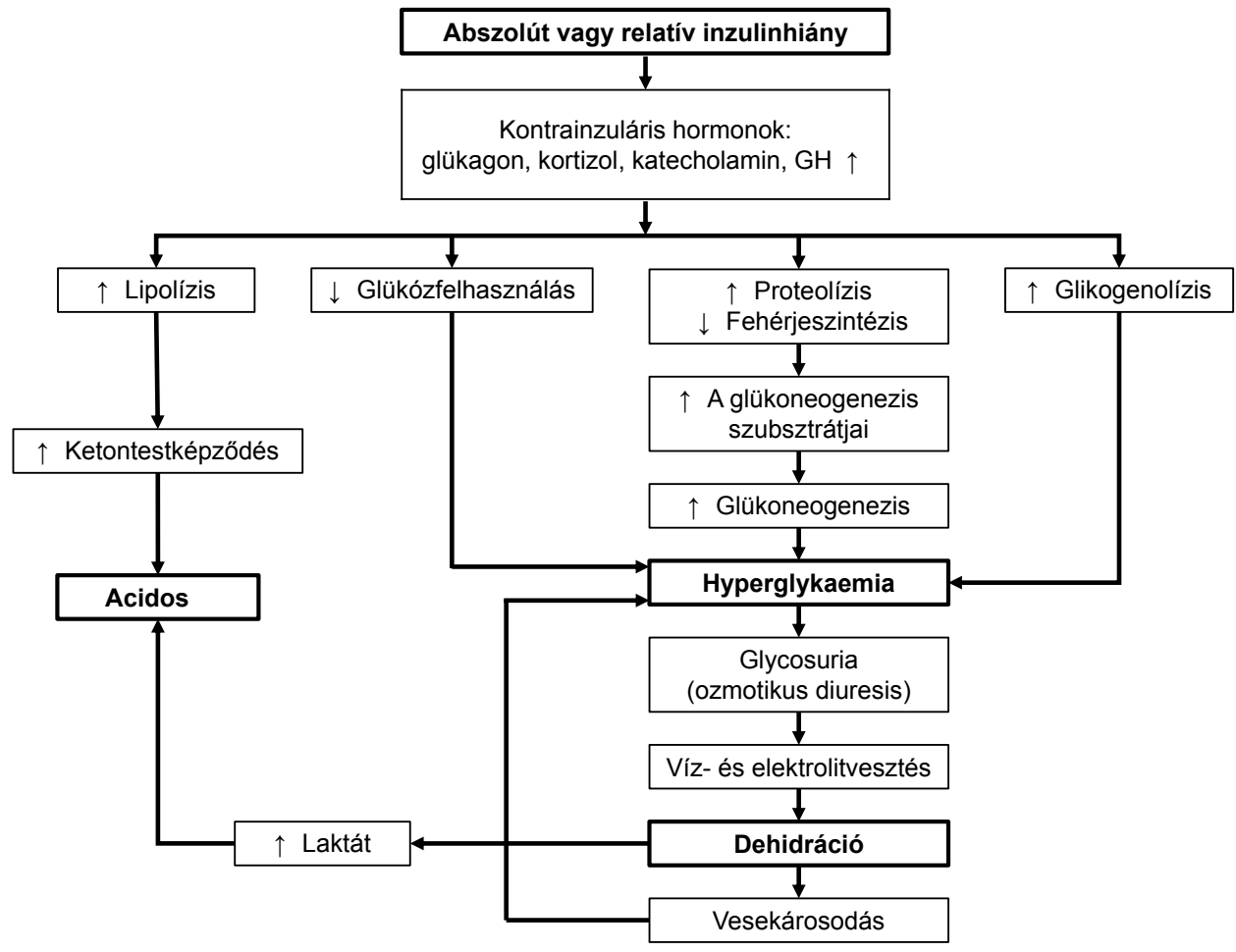

1. ábra

A DKA kialakulásának folyamata (Wolfsdorf és mtsai [6] alapján)

$\mathrm{DKA}=$ diabeteses ketoacidosis; $\mathrm{GH}=$ növekedési hormon 
kevéssé feltérképezett területe, az irodalomban alig találunk erre való hivatkozást, habár a laktát napjainkban az intenzív terápia egyik központi prognosztikai és a terápia hatásosságát jelző faktorává vált $[7,8]$. A korszerü vérgáz-analizátorok ezért általában már képesek a laktát (kizárólag az L-laktát) meghatározására.

A laktát a szervezetben L- és D-izomerként van jelen. Az emberi testben a laktát minimum 95\%-át az L-laktát teszi ki, a D-laktát csupán elenyésző mennyiségben termelődik. Az L-laktát a glikolízis végtermékéből, a piruvátból jön létre a laktátdehidrogenáz $(\mathrm{LDH})$ által katalizált reverzibilis reakció során, miközben a $\mathrm{NADH}$ $\mathrm{NAD}^{+}$-dá oxidálódik. A piruvát összekötő kapocs szervezetünk két fó energiatermelő folyamata, a glikolízis és az oxidatív foszforiláció között. Az emberi testben naponta megközelítőleg $20 \mathrm{mmol} / \mathrm{ttkg}$ laktát keletkezik, de normális körülmények között a termelődés és a lebontás egyensúlyban van, ami stabil, 1-1,5 mmol/1 laktátszintet eredményez. Szöveti hypoxiával járó állapotokban az oxidatív foszforiláció elégtelensége miatt az egyensúly a laktát oldalára tolódik el, és hyperlactataemia alakul ki. Anaerob körülmények között ez a folyamat nélkülözhetetlen a folyamatos glikolízis biztosítása érdekében. Hyperlactataemia azonban nem csak anaerob körülmények között jöhet létre. A sejtet érő stresszállapotokban az aerob glikolízis sebessége akár 100-1000-szeresre fokozódhat a megfelelő energiaellátás érdekében, ami szintén a laktát felhalmozódásához vezet. Ha a kiváltó hatás megszűnik, a laktát visszaalakul piruváttá és lebomlik a citrátkörben, majd az oxidatív foszforilációban. Az aerob glikolízis és a szöveti hypoxia nem egymást kizáró tényezők, bizonyos körülmények között mindkettő hozzájárulhat a hyperlactataemia kialakulásához. Ezek a folyamatok tehát az L-laktát-produkcióért felelősek [7-11]. A normálisan kis mennyiségű D-laktát egyrészt a bélbaktériumok bomlásterméke, másrészt a normál-cukoranyagcsere során képződő metil-glioxálból alakul ki. Korábbi vizsgálatok már rámutattak arra, hogy DKA-ban a metil-glioxál és így a D-laktát szintje is emelkedett, ami a ketontesteken kívül szintén hozzájárul a magas anion 'gap'-pel járó acidosishoz [7, 9]. A DKA ellátása során vett sorozatos vérgázkontrollok az utóbbi években hívták fel a figyelmünket arra, hogy a súlyos folyadékhiány okozta evidens laktátkoncentráció-emelkedés nem gyorsan múló jelenség. A szakirodalom nem nyújt magyarázatot erre a megfigyelésre, ezért kutatásunk során azt tüztük ki célul, hogy pontosan feltérképezzük a DKAban látott laktátváltozások kinetikáját, és vizsgáljuk a háttérben álló lehetséges mechanizmusokat.

\section{Betegek és módszer}

Prospektív vizsgálatunkba a Semmelweis Egyetem I. Gyermekgyógyászati Klinikájának Diabetes, Endokrinológiai és Metabolikus Osztályán 2015. 04. 01. és 2015. 12. 31. között kezelt betegeket vontunk be. Az egyik vizsgálati csoportot ketoacidosis állapotában felvett
(DKA-csoport, $\mathrm{n}=13$ ) gyermekek, a másik csoportot frissen diagnosztizált, vérgázegyensúlyban lévő, l-es típusú diabetes betegek (T1DM-csoport, $\mathrm{n}=6$ ) alkották. A vizsgálatok a Semmelweis Egyetem Regionális, Intézményi Tudományos és Kutatásetikai Bizottságának engedélyével zajlottak. Minden vizsgálati résztvevő törvényes képviselője írásos, tájékozott beleegyezést adott a vizsgálathoz.

A két vizsgálati csoport alapvető jellemzőit az 1. táblázat tartalmazza. Természetes különbség a két csoport között a diabetes fennállásának tartamában és a kezdeti pH-értékben látható, az életkor tekintetében nem volt szignifikáns különbség. A nemek aránya DKA-ban a fiúk, míg a TIDM-csoportban a lányok javára tolódott el. A betegek ellátása minden alkalommal az I. Gyermekklinika Diabetes, Endokrinológiai és Metabolikus vagy Intenzív Osztályán zajlott. A DKA terápiája az International Society for Pediatric and Adolescent Diabetes (ISPAD) 2014-es irányelveinek megfelelően történt. A frissen diagnosztizált diabeteses, nem acidoticus gyermekeket az első 48 órában gyors és intermedier hatású humán monokomponensű szubkután inzulinnal kezeltük.

Közvetlenül a felvételt követően a rutinvizsgálat részeként vérgázanalízis (Astrup-vizsgálat) történt kapillárisvérmintából (GEM 3000, Instrumentation Laboratory, Bedford, MA, Amerikai Egyesült Államok), mely az alapvető vérgázparaméterek mellett az L-laktát-szint mérésére is képes. A laktátkoncentráció-változás kinetikájának megismerése céljából a szokásos kezdeti 2-4 óránként végzett laboratóriumi kontrollon túl 12, 24 és 48 óra után is megismételtük az Astrup-vizsgálatot. Az L-laktát értékét 1,5 mmol/l-ig tekintettük normálisnak. Ezzel párhuzamosan minden időpontban vénás vérvétel történt az összlaktát (D + L-laktát) meghatározására a klinika Anyagcsere Laboratóriumában gázkromatográfiás tömegspektrometriával (GC-MS) $(n=9+6)$. Fontos hangsúlyozni, hogy a klinikai gyakorlatban rutinszerúen használt vérgáz-analizátorok kizárólag az L-lak-

1. táblázat |A vizsgálati csoportok fó jellemzői

\begin{tabular}{lcc}
\hline & DKA & T1DM \\
\hline Esetszám & 13 & 6 \\
Életkor [átlagév (SD)] & $12,38(2,5)$ & $11,8(4,7)$ \\
Diabetestartam [átlagév (SD)] & $6,83(2,4)$ & $\begin{array}{c}\text { Frissen } \\
\text { diagnosztizált }\end{array}$ \\
Fiú/lány arány & $8: 5$ & $1: 5$ \\
$\begin{array}{l}\text { Kezdeti vércukorszint [átlag, } \\
\text { mmol/1 (SD)] }\end{array}$ & $25,03(9,8)$ & $22,5(9,2)$ \\
Kezdeti pH [átlag (SD)] & $7,11(0,1)$ & $7,4(0,01)$ \\
$\begin{array}{l}\text { Kezdeti laktátszint } \\
\text { [átlag, mmol/1 (SD)] }\end{array}$ & $3,97(1,9)$ & $1,8(0,5)$ \\
\hline
\end{tabular}

$\mathrm{DKA}=$ diabeteses ketoacidosis; $\mathrm{SD}=$ standard deviáció; $\mathrm{T} 1 \mathrm{DM}=1$-es típusú cukorbetegség 
tátot képesek detektálni, ezzel szemben a laboratóriumi GC-MS-módszer nem tesz különbséget a két izomer között, tehát alkalmas az összlaktát-koncentráció meghatározására. Az összlaktát értékét $3,3 \mathrm{mmol} / \mathrm{l}$ alatt tekintettük normálisnak. A D-laktát szintjére az össz- és az L-laktát-koncentrációk különbségéből, indirekt módon következtethetünk.

Az adatok statisztikai elemzését varianciaanalízissel végeztük, és a p<0,05 értéket tekintettük a szignifikancia szintjének.

\section{Eredmények}

A 0. időpontban (felvételkor) minden DKA-betegnél kórosan emelkedett L-laktát-koncentrációt mértünk $(3,97 \pm 1,9 \mathrm{mmol} / \mathrm{l})$. A két csoportot összehasonlítva az L-laktát-szint a 0 . időpontban a DKA-csoportban szignifikánsan magasabb volt $(\mathrm{p}<0,05)$, mint a T1DM-csoportban, de az utóbbiban is gyakori volt a hyperlactataemia. A későbbi időpontokban ez a különbség eltünt (2. és 3. ábra).

12 óra elteltével, a rehidráció fázisában az L-laktát a DKA-csoportban szignifikánsan csökkent $(2,05 \pm 0,9$ $\mathrm{mmol} / \mathrm{l}, \mathrm{p}<0,01)$, sok esetben normalizálódott, majd a terápia folytatásának ellenére a 12 órás értékhez képest ismételten szignifikánsan megemelkedett 24 óra $(3,07 \pm$ $1,4 \mathrm{mmol} / 1, \mathrm{p}<0,01)$ és 48 óra $(4,02 \pm 1,7 \mathrm{mmol} / 1$, $\mathrm{p}<0,01)$ után. A második L-laktát-emelkedés során a laktát koncentrációja több esetben még a kezdetben mért magas értékeket is meghaladta. A friss diabeteses csoportban 12 és 24 óra után nem volt jelentős változás, viszont 48 óra után az L-laktát-koncentráció ebben a csoportban is szignifikánsan magasabb volt, mint 12 óra után $(3,24 \pm 1,3 \mathrm{mmol} / 1, \mathrm{p}<0,05)$ (2. és 3. ábra).

Habár az összlaktátszint kezdetben kissé magasabb volt DKA-ban, mint friss diabetesben, a két csoport között egyik időpontban sem volt szignifikáns különbség, ezért a továbbiakban ennek alakulását az összes beteget együtt vizsgálva elemeztük. Az összlaktát-koncentráció a vizsgálat kezdetén $(\mathrm{p}<0,005), 12$ óra után $(\mathrm{p}<0,001)$ és 24 óra után $(\mathrm{p}<0,05)$ is szignifikánsan magasabb volt, mint az L-laktát-koncentráció. Hangsúlyozandó, hogy az eltérő metodikával történő meghatározások eredményét közvetlenül összehasonlítani nem lehet, de ezt a különbséget tekinthetjük úgy, mint a D-laktátot tükröző érték. Az összlaktát- és az L-laktát-szint közötti kezdeti különbség folyamatosan csökkenve 24 óra után minimálissá vált, 48 óra után pedig már nem volt kimutatható, jelezve a D-laktát-felhalmozódás csökkenő mértékét az inzulinkezelés folyamán (4.ábra).

\section{Következtetés}

Vizsgálatunk során a DKA miatt felvett és kezelt betegeket frissen diagnosztizált diabeteses betegekkel összehasonlítva értékeltük. A csoportok kialakítása során abból indultunk ki, hogy ketoacidosisos betegekben izoláltan tudjuk kimutatni az acidosis és a súlyos folyadékhiány és

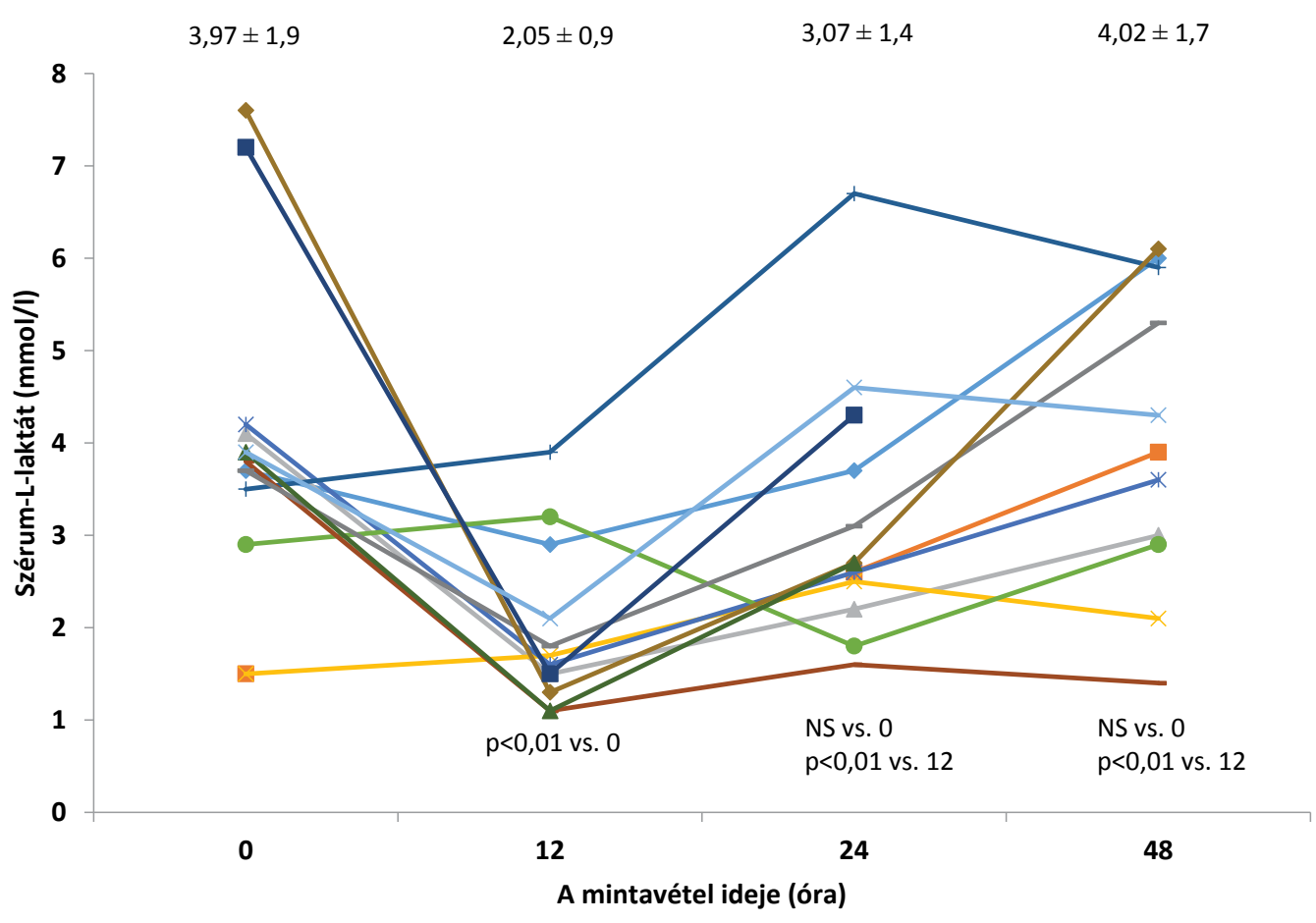

2. ábra $\quad$ Az L-laktát-koncentráció változása a DKA-csoportban (az egyes időpontokban mért értékek közötti szignifikanciaszintekkel; NS: nincs szignifikáns különbség)

DKA $=$ diabeteses ketoacidosis 


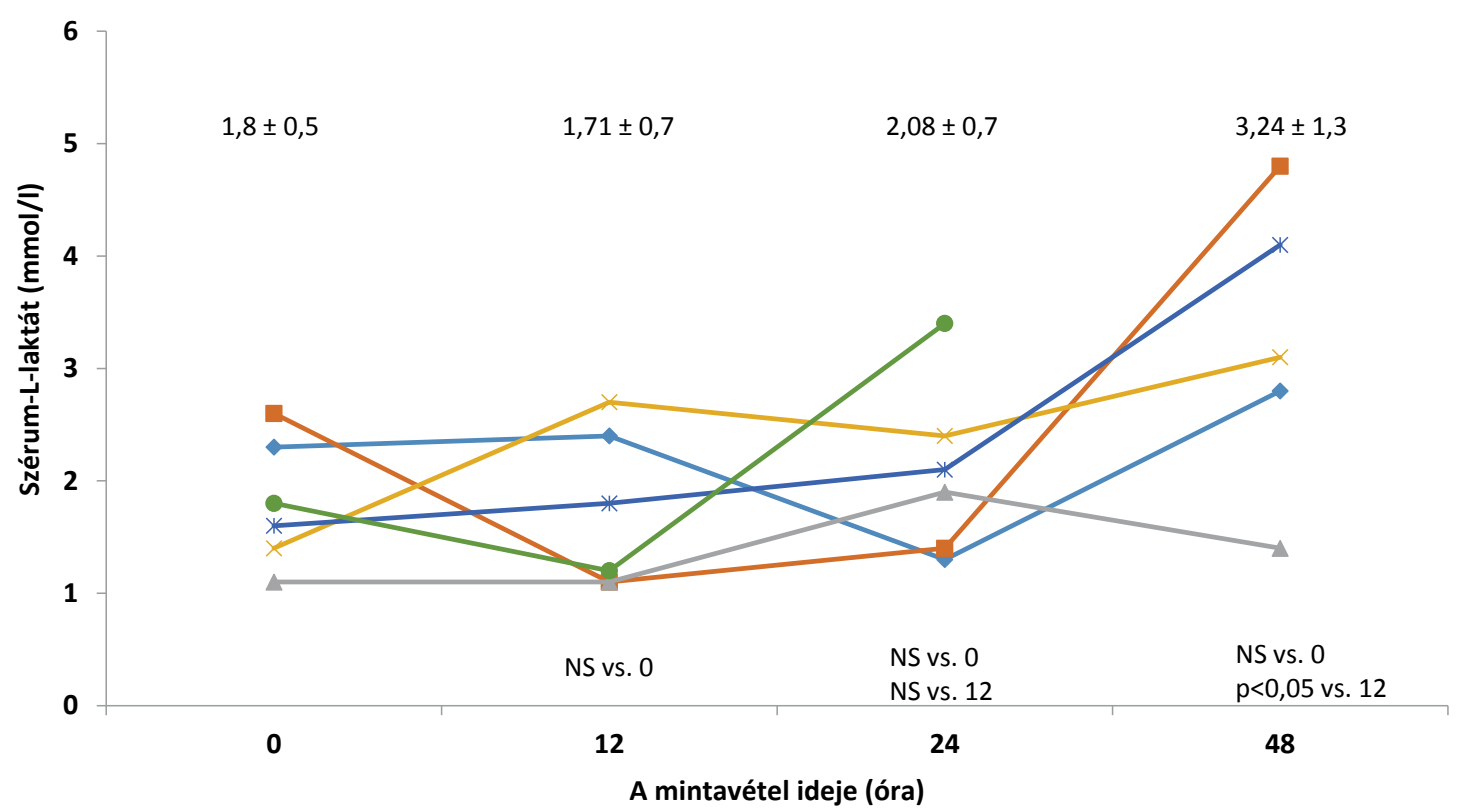
\begin{tabular}{l|l} 
3. ábra & $\begin{array}{l}\text { Az L-laktát-koncentráció változása a frissen diagnosztizált diabeteses (TIDM-) csoportban ketoacidosis nélkül (NS: nincs szignifikáns különbség) } \\
\text { TIDM = 1-es típusú cukorbetegség }\end{array}$
\end{tabular}

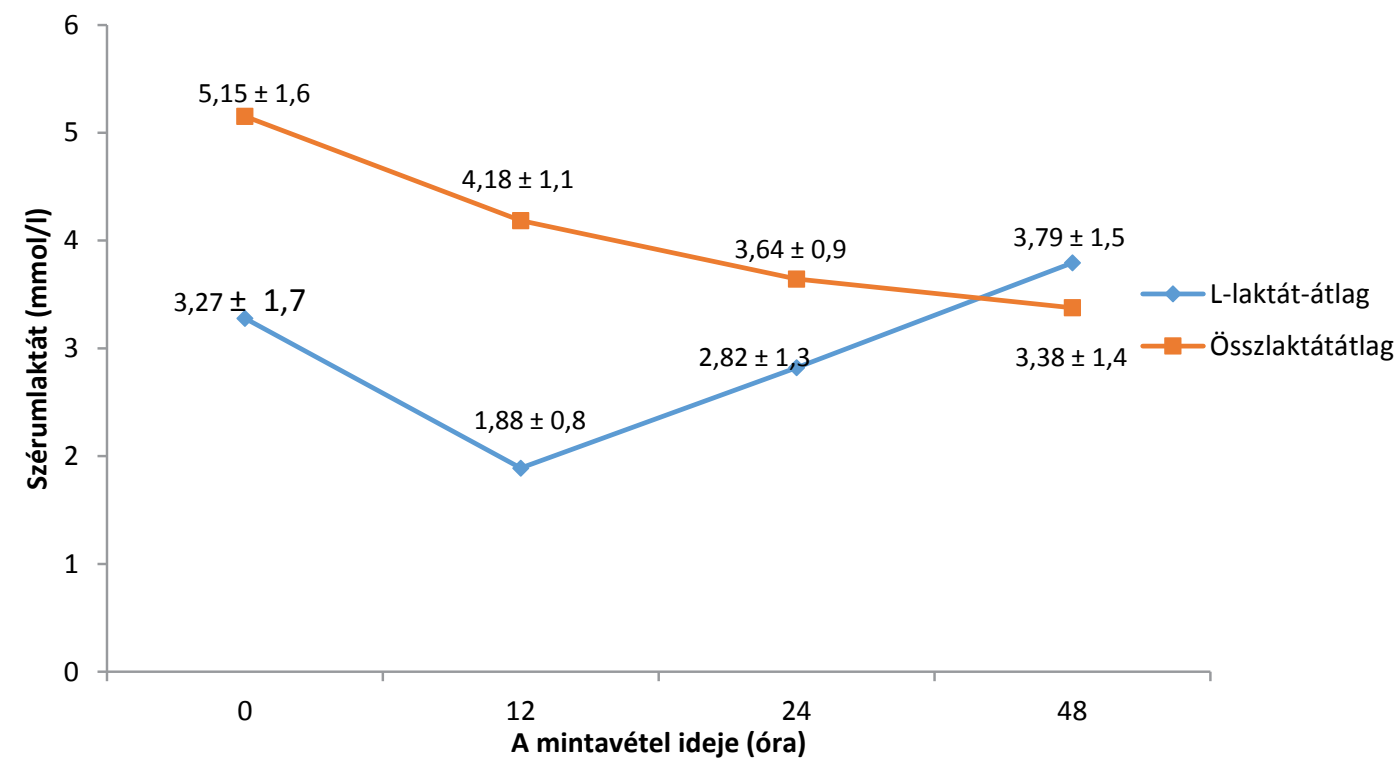

4. ábra $\mid$ Az összes beteg L-laktát- és összlaktátkoncentráció-változásának összehasonlítása (az egyes idôpontokban mért koncentrációk átlagai és szórásai a görbék felett: az L- és összlaktát meghatározása eltérő metodikával történt, ezért statisztikai összehasonlítást nem végeztünk)

szöveti keringészavar hatásait, míg a friss diabeteses csoportra általában enyhébb mértékü, keringészavart nem okozó dehidráció jellemző, mely jellemzően nem okoz anaerob anyagcsere-eltérést sem. A két csoport közös jellemzője ezzel szemben az inzulinhiány és a jelentős hyperglykaemia, ezért ennek hatását mindkét betegcsoportban vizsgálhattuk.

A felvételkor (0. óra) végzett mintavételnél egységesen jellemző volt a DKA-csoport minden betegére az enyhétől súlyosig terjedő hyperlactataemia (L-laktát), mely a frissen diagnosztizált diabeteses csoport betegei- nél szignifikánsan kisebb mértékben volt megfigyelhető. Ez a kezdeti laktátemelkedés ismert jelenség ketoacidosisban, és hátterében a hypovolaemia okozta szöveti hypoperfusio és a következményes anaerob glikolízis biztosan fószerepet játszik. Ezt alátámasztja a két csoport közötti különbség is, hiszen a folyadékhiány, éppúgy, mint a hyperlactataemia, a nem ketoacidosisos betegeknél kevésbé volt jelentős. A hypovolemia szerepére utal továbbá az is, hogy a folyadékresuscitatio hatására, 12 óra elteltével DKA-ban az L-laktát szignifikánsan csökkent, sok esetben normalizálódott is. Ezzel szemben 
a T1DM-csoportban 12 óra után nem észleltünk számottevő változást.

A magas laktátszint normalizálódását követően folytatott mintavételek során mindkét csoportban meglepő tendenciát figyeltünk meg. A terápia folytatása ellenére a felvételtól számított 12 . óra után egy második L-laktátemelkedést tapasztaltunk, melyet a 48. óráig észleltünk, és a DKA-csoportban már 24 óra után is, a T1DM-csoportban pedig 48 óra után szignifikáns mértékü volt. Az újabb növekedés a friss diabeteses csoportban kismértékben elmaradt a DKA-csoport mögött. A 48 órás érték sok esetben a kezdetben mért laktátszintet is meghaladta. Ez a jelenség korábban nem volt ismert a szakirodalomban, DKA miatt kezelt betegeinknél a klinikai gyakorlatban azonban hosszabb ideje megfigyeltük, de a frissen diagnosztizált T1DM-betegek esetében - mivel náluk nem történik vérgázkövetés - ez eddig számunkra is ismeretlen jelenség volt. A kezelésnek ebben a fázisában a betegek folyadékháztartása és vércukorértéke már rendezett, klinikai tüneteik is megszünnek, tehát a második laktátcsúcsot nem magyarázhatja a kezdetben kézenfekvő hypovolaemia és szöveti hypoxia, illetve a jelentős hyperglykaemia.

Jól ismert tény, hogy bizonyos celluláris stresszhatások következtében a nagy energiaigény biztosítása érdekében az aerob glikolízis sebessége $2-3$ nagyságrenddel is megnövekedhet, feltéve, hogy elegendő mennyiségú glükóz van jelen, és a felhalmozódott piruvátból folyamatosan laktát képződhet. Fokozott energiaigény esetén tehát a laktát nélkülözhetetlen pufferként funkcionál, ami lehetővé teszi a glikolízis felgyorsulását. Ennek ismeretében a 24-48 óra után tapasztalt hyperlactataemia hátterében feltételezhető az inzulinkezelés következtében helyreálló intracelluláris glükózellátottság és a nagy energiaigényű stresszhelyzetben fokozódó aerob glikolízis is. Ez a metabolikus út célszerú adaptációként jelentôs mennyiségű laktátfelhalmozódáshoz vezethet. Vizsgálati eredményeink alapján ezt a mechanizmust nem tudjuk igazolni, de a kórélettani történések logikája alapján feltételezhetjük döntő szerepét a laktátkoncentrációk 24 , illetve 48 óra után tapasztalt ismételt emelkedésének hátterében mindkét vizsgálati csoportban.

Az irodalomból ismert, hogy hyperglykaemia, illetve DKA során D-laktát-felhalmozódás is jelentkezik, ami hozzájárulhat a hyperlactataemiához és az acidosishoz. Mivel a klinikai gyakorlatban használt vérgáz-analizátorok kizárólag az L-laktátot detektálják, ezt a lehetséges mechanizmust az összlaktátszint $(\mathrm{D}+\mathrm{L})$ párhuzamos vizsgálata segítségével közelítettük meg. A D-laktát jelenlétére az összlaktát és az L-laktát közötti különbségből következtettünk. A két csoport között az összlaktát tekintetében nem volt lényeges különbség. Az összlaktát-koncentráció a 0 . időpontban, 12 és 24 óra után is szignifikánsan magasabb volt, mint az L-laktát-koncentráció. Az összlaktát-koncentráció a vizsgálat kezdetén átlagosan közel 2,5 mmol/l-rel haladta meg az L-laktátszintet, majd a vizsgálat során egyenletesen csökkent, így a különbség 48 óra után teljesen eltúnt (4. ábra). Az egyébként jelentéktelen mennyiségben megtalálható Dlaktát a glükóz metabolizmusa során jön létre. Ketoacidosisban ehhez hozzájárul a ketontestek lebontása során képződő D-laktát is. A 0 . időpontban a D-laktát koncentrációja összemérhető az L-laktát-koncentrációval, tehát ketoacidosis során a ketontesteken és az L-laktáton kívül biztosan hozzájárul a magas anion 'gap'-pel járó metabolikus acidosishoz. A fokozatosan csökkenő Dlaktát-produkciót mindkét csoportban az adekvát terápia miatt csökkenő vércukorszint, emellett DKA-ban egyúttal a mérséklődő ketontestképződés következményének tartjuk.

Összefoglalva, DKA során két L-laktát-emelkedést írtunk le. Ezt a jelenséget a klinikai gyakorlatban az Astrup-vizsgálatok során észlelhetjük. Ismerete fontos lehet, hiszen a jól kezelt ketoacidoticus betegek esetén is számítanunk kell a 24-48 óra elteltével ismételten megemelkedő laktátértékekre, ami ebben az esetben nem a terápia elégtelenségét vagy a rossz prognózist jelzi, hanem a ketoacidosis gyógyulási folyamatának természetes velejárója. Vizsgálatunk alátámasztotta, hogy a normálisan elenyésző mennyiségú és általában nem vizsgált Dlaktát ketoacidosisban és frissen diagnosztizált diabetesben is számottevő mennyiségben képződik. DKA ellátása során, már normális laktát és megszünt ketonuria ellenére, elhúzódó acidosis esetén gondolnunk kell a D-laktát szerepére.

Anyagi támogatás: A kutatómunka és a közlemény megírása anyagi támogatásban nem részesült.

Szerzôi munkamegosztás: J. K.: A kutatási koncepció kidolgozása, mintagyújtés, statisztikai értékelés, a kézirat elkészítése. Sz. I.: Az anyagcsere-vizsgálatok elvégzése, a kézirat elkészítése. Sz. E.: Az anyagcsere-vizsgálatok elvégzése. M. A.: Mintagyưjtés, statisztikai értékelés, a kézirat értékelése. L. A.: A betegek klinikai kezelése, a kézirat értékelése. Zs. P.: Az anyagcsere-vizsgálatok feldolgozása, a kézirat értékelése. T.-H. P.: A kutatási koncepció kidolgozása, klinikai kezelés, statisztikai értékelés, a kézirat elkészítése.

Érdekeltségek: A szerzőknek nincsenek érdekeltségeik.

\section{Irodalom}

[1] Gyürüs É, Soltész G, Magyar Gyermekdiabétesz Epidemiológiai Munkacsoport. Epidemiology of ketoacidosis in children at presentation of diabetes in Hungary (2002-2009). [A gyermekkori diabeteses „prezentációs ketoacidosis” epidemiológiája Magyarországon (2002-2009).] Gyermekgyógyászat 2014; 65: 36-40. [Hungarian]

[2] H Nagy K, Soltész Gy. Significance, early diagnosis and treatment of diabetic ketoacidosis in children. [A gyermekkori diabéteszes ketoacidosis jelentősége, korai felismerése és kezelése.] Gyermekgyógy Továbbk Szle. 2015; 20: 136-139. [Hungarian] 
[3] Chou YM, Seak CJ, Goh ZN, et al. Euglycemic diabetic ketoacidosis caused by dapagliflozin: a case report. Medicine (Baltimore) 2018; 97: el1056.

[4] Badwal K, Tariq T, Peirce D. Dapagliflozin-associated euglycemic diabetic ketoacidosis in a patient presenting with acute pancreatitis. Case Rep Endocrinol. 2018; 2018: 6450563.

[5] Pujara S, Ioachimescu A. Prolonged ketosis in a patient with euglycemic diabetic ketoacidosis secondary to dapagliflozin. J Investig Med High Impact Case Rep. 2017; 5: 2324709617710040.

[6] Wolfsdorf JI, Allgrove J, Craig ME, et al. ISPAD Clinical Practice Consensus Guidelines 2014. Diabetic ketoacidosis and hyperglycemic hyperosmolar state. Pediatr Diabetes 2014; 15(Suppl 20): 154-179.

[7] Cox K, Cocchi MN, Salciccioli JD, et al. Prevalence and significance of lactic acidosis in diabetic ketoacidosis. J Crit Care 2012; 27: 132-137.
[8] Kraut JA, Madias NE. Lactic acidosis. N Engl J Med. 2014; 371 : 2309-2319.

[9] Lu J, Zello GA, Randell E, et al. Closing the anion gap: contribution of D-lactate to diabetic ketoacidosis. Clin Chim Acta 2011; 412: 286-291.

[10] Adeva-Andany M, López-Ojén M, Funcasta-Calderón R, et al. Comprehensive review on lactate metabolism in human health. Mitochondrion 2014; 17: 76-100.

[11] Bakker J, Nijsten MW, Jansen TC. Clinical use of lactate monitoring in critically ill patients. Ann Intensive Care 2013; 3: 12.

(Tóth-Heyn Péter dr.,

Budapest, Bókay J. u. 53., 1083

e-mail: toth-heyn.peter@med.semmelweis-univ.hu)

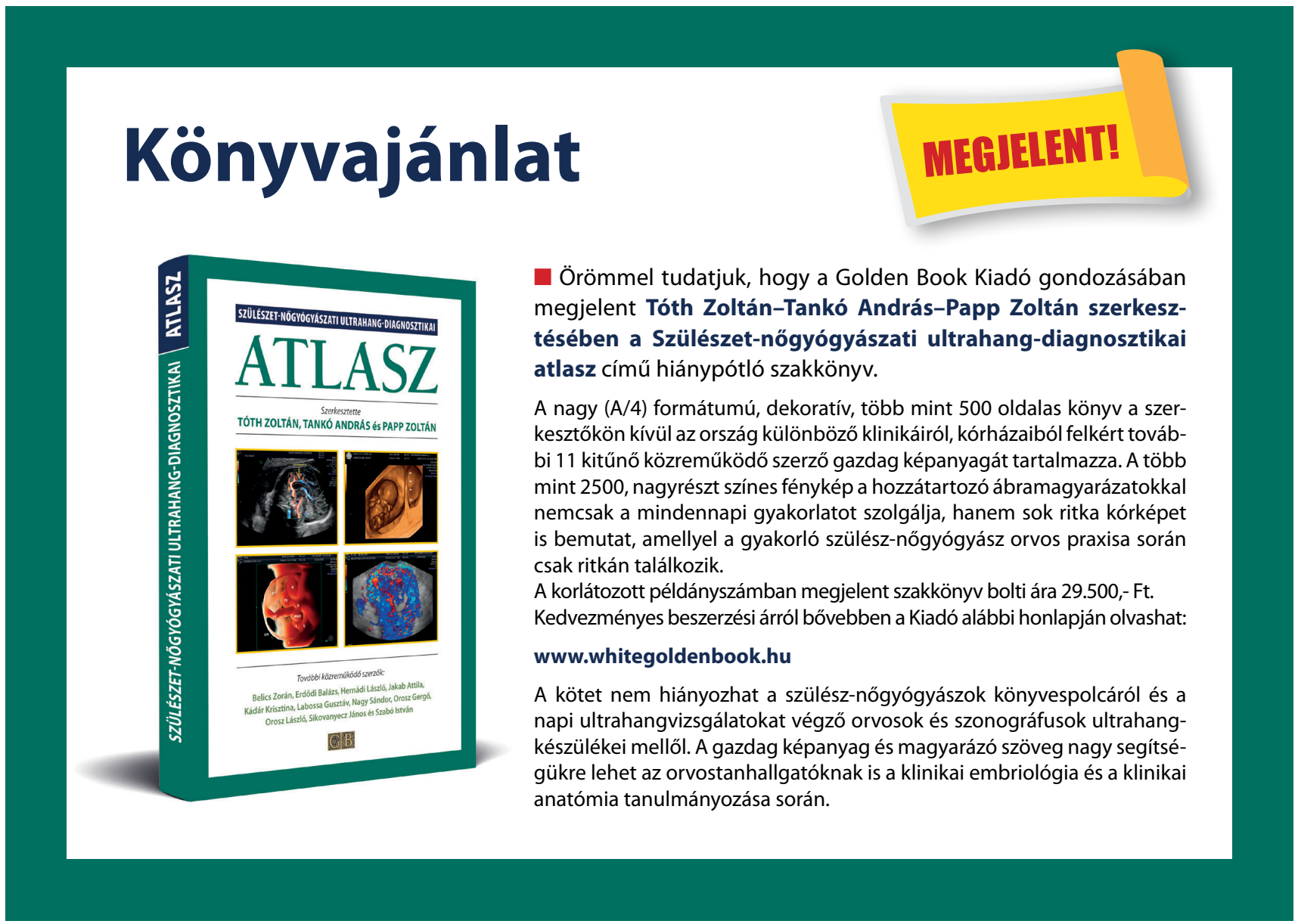

A cikk a Creative Commons Attribution 4.0 International License (https://creativecommons.org/licenses/by/4.0/) feltételei szerint publikált Open Access közlemény, melynek szellemében a cikk bármilyen médiumban szabadon felhasználható, megosztható és újraközölhetö, feltéve, hogy az eredeti szerző és a közlés helye, illetve a CC License linkje és az esetlegesen végrehajtott módosítások feltüntetésre kerülnek. (SID_1) 